\begin{tabular}{|l|lll|}
\hline & Journal : Small 10526 & Dispatch : 26-10-2007 & Pages : 17 \\
& Article No. : 9132 & $\square$ LE & $\square$ TYPESET \\
MS Code : BICO 634 & $\checkmark \mathrm{CP}$ & $\checkmark$ DISK \\
\hline
\end{tabular}

\title{
3 Harmonia axyridis in Europe: spread and distribution 4 of a non-native coccinellid
}

\author{
5 P. M. J. Brown - T. Adriaens - H. Bathon - J. Cuppen - A. Goldarazena • \\ 6 T. Hägg • M. Kenis · B. E. M. Klausnitzer · I. Kovář • A. J. M. Loomans • \\ 7 M. E. N. Majerus · O. Nedved · J. Pedersen · W. Rabitsch · H. E. Roy • \\ 8 V. Ternois $\cdot$ I. A. Zakharov $\cdot$ D. B. Roy
}

9 Received: 18 August 2007/ Accepted: 21 October 2007

10 (C) International Organization for Biological Control (IOBC) 2007

11 Abstract Native to Asia, Harmonia axyridis (Pallas) (Coleoptera: Coccinellidae) is 12 considered an invasive alien ladybird in Europe and North America, where it was widely 13 introduced as a biological control agent of aphids and coccids. In Europe, $H$. axyridis was 14 sold by various biological control companies from 1995 in France, Belgium and the 15 Netherlands, and was also intentionally released in at least nine other countries. It has 16 spread very rapidly, particularly since 2002, and is now regarded as established in thirteen 17 European countries. The established range extends from Denmark in the north to southern

A1 P. M. J. Brown $(\varangle) \cdot$ H. E. Roy · D. B. Roy

A2 NERC Centre for Ecology and Hydrology - Monks Wood, Huntingdon PE28 2LS, UK

A3 e-mail: pmb@ceh.ac.uk

A4 P. M. J. Brown - H. E. Roy

A5 Department of Life Sciences, Anglia Ruskin University, East Road, Cambridge CB1 1PT, UK

A6 T. Adriaens

A7 Instituut voor Natuur- en Bosonderzoek, Kliniekstraat 25, 1070 Brussel, Belgium

A8 H. Bathon

A9 Federal Biological Research Centre for Agriculture and Forestry, Institute for Biological Control,

A10 Heinrichstr. 243, 64287 Darmstadt, Germany

A11 J. Cuppen

A12 Wageningen University, P. O. Box 8080, 6700 DD Wageningen, Netherlands

A13 A. Goldarazena

A14 Neiker-Tecnalia, Instituto Vasco de Investigación y Desarrollo Agrario, Centro Arkaute, Apdo. 46,

A15 01080 Vitoria-Gasteiz Alava, Pais Vasco, Spain

A16 T. Hägg

A17 Kristianstadgatan 15, 21423 Malmo, Sweden

A18 M. Kenis

A19 CABI Europe-Switzerland, 2800 Delemont, Switzerland

A20 B. E. M. Klausnitzer

A21 Institut für Ökologie und Entomologie, Lannerstraße 5, 01219 Dresden, Germany 


\begin{tabular}{|l|lll|}
\hline & Journal : Small 10526 & Dispatch : 26-10-2007 & Pages : 17 \\
Article No. : 9132 & $\square$ LE & $\square$ TYPESET \\
MS Code : BICO 634 & $\checkmark \mathrm{CP}$ & $\checkmark$ DISK \\
\hline
\end{tabular}

P. M. J. Brown et al.

France in the south, and from Czech Republic in the east to Great Britain in the west. In this paper we map the spread and distribution of $H$. axyridis in Europe, and examine the situation on a country-by-country basis. We report first records of the species in five countries; Spain, Sweden, Denmark, Czech Republic and Italy; and first evidence of $H$. axyridis establishment in the latter three countries. Despite releases of $H$. axyridis in Portugal, Spain and Greece, there is little evidence of establishment in southern Europe. It is predicted that the spread and increase within Europe will continue and that $H$. axyridis will become one of the most widely distributed coccinellids in the continent.

Keywords Biological control · Coccinellidae $\cdot$ Halloween beetle $\cdot$ Harlequin ladybird · Harmonia axyridis · Introduced species · Invasive species ·

Multicolored Asian lady beetle $\cdot$ Non-native species

\section{Background to Harmonia axyridis}

Variously known as the multicolored Asian lady beetle, Halloween beetle and harlequin ladybird, Harmonia axyridis (Pallas) (Coleoptera: Coccinellidae), is native to China, Japan, Korea, Mongolia and Siberia (e.g. Dobzhansky 1933; Kuznetsov 1997), although its entire native range, particularly in parts of the former Soviet Union, has not been clearly recorded. Although usually stated in the literature to be semi-arboreal (e.g. Hodek 1973), it occupies many habitats, and in parts of both its native and introduced ranges has been recorded in meadows, heathlands and riparian zones (Adriaens et al. submitted to BioControl SI), reedbeds (Ware et al. 2005; Brown et al. submitted to BioControl SI) and crop systems (Colunga-Garcia and Gage 1998).

I. Kovár

The Natural History Museum, Kunratice 1, 14800 Praha 4, Czech Republic

A. J. M. Loomans

Department of Entomology, National Reference Laboratory, Plant Protection Service, P. O. Box 9102, 6700 HC Wageningen, Netherlands

\section{E. N. Majerus}

Department of Genetics, University of Cambridge, Downing Street, Cambridge CB2 3EH, UK

\section{O. Nedved}

Faculty of Science, University of South Bohemia, Branišovská 31, 37005 Ceske Budejovice, Czech Republic

J. Pedersen

Zoological Museum, University of Copenhagen, Universitetsparken 15, 2100 Kobenhavn, Denmark

W. Rabitsch

Federal Environment Agency, Spittelauer Lände 5, 1090 Wien, Austria

\section{Ternois}

Observatoire permanent pour le suivi de la Coccinelle asiatique en France, CPIE du Pays de Soulaines, Domaine de Saint-Victor, 10200 Soulaines-Dhuys, France

\section{A. Zakharov}

Vavilov Institute of General Genetics RAS, Moscow 119991, Russia 


\begin{tabular}{|l|lll|}
\hline & Journal : Small 10526 & Dispatch : 26-10-2007 & Pages : 17 \\
& Article No. : 9132 & $\square$ LE & $\square$ TYPESET \\
MS Code : BICO 634 & $\checkmark$ CP & $\checkmark$ DISK \\
\hline
\end{tabular}

Harmonia axyridis in Europe

The species has a long history of use as a classical biological control agent of aphids and coccids in North America, where it was first introduced in 1916 (Gordon 1985). It has been widely used for pest control in crops as diverse as pecans (Tedders and Schaefer 1994) and red pines (McClure 1987). As a biological control agent $H$. axyridis has incidentally succeeded in controlling pest aphid species on other crops, including apples (Brown and Miller 1998) and citrus fruits (Michaud 2002). Despite releases in fourteen US states between 1964 and 1982 (Gordon 1985), H. axyridis was not reported as established in the country until 1988 (Chapin and Brou 1991). There is uncertainty over the source of the established US population, which may originate from a single intentional release or accidental introduction (Krafsur et al. 1997). Day et al. (1994) suggested that the source could have been accidental seaport introductions.

Harmonia axyridis has recently been recorded in South America (de Almeida and da Silva 2002) and South Africa (N. Mgocheki, personal communication; J. Hatting, personal communication), and has been introduced in Egypt (Ferran et al. 2000) where it has become established around Cairo (S. Elnagdy, personal communication).

In Europe early introductions of $H$. axyridis occurred in the east, including to Ukraine from 1964 (for control of aphids on fruit trees) (Katsoyannos et al. 1997) and Belarus from 1968 (Sidlyarevich and Voronin 1973). In western Europe, H. axyridis was first used as a biological control agent in 1982 in France and first marketed in 1995 (Coutanceau 2006). Various companies subsequently made the species commercially available (Adriaens et al. 2003).

In a risk assessment of 31 exotic natural enemies of pest species used in biological control in Europe, $H$. axyridis had the second highest environmental risk index. This was based on its wide host range (i.e. multiple prey species), ability to establish and disperse, and direct and indirect effects on non-target species (van Lenteren et al. 2003). Van Lenteren et al. (submitted to BioControl SI) concluded that there are no easy ways to mitigate or reduce the risk of $H$. axyridis and that it should not have been released in northwest Europe.

The aim of this paper is to present a thorough examination of the history, spread and distribution of $H$. axyridis in Europe. The data are an amalgamation of records of the occurrence of $H$. axyridis in Europe, mapped at $50 \mathrm{~km}$ resolution. Records were verified by the authors, derived from published papers, and/or made by experienced naturalists.

\section{Countries in which $\boldsymbol{H}$. axyridis was introduced as a biological control agent}

\section{Belgium}

Harmonia axyridis was used as a biological control agent in Belgium from 1997 (Adriaens et al. 2003). A large-scale ladybird field survey (Coccinula-Belgian ladybird working group, http://www.inbo.be/content/page.asp?pid=EN_FAU_INS_LAD_start) was launched in 1999 in the Walloon region, and 2001 in the Flemish region (Adriaens et al. 2003). By 2007 Coccinula had in excess of 500 volunteer surveyors (Adriaens et al. submitted to BioControl SI), hence coccinellids are very well recorded in Belgium. Harmonia axyridis was first found in the wild in Belgium in autumn 2001, in both Ghent and Brussels (Adriaens et al. submitted to BioControl SI) and the invasion probably originated from populations in the north of the country. By 2003, H. axyridis was found in large overwintering aggregations comprising 500+ individuals (Adriaens et al. submitted to BioControl SI) and was invading semi-natural ecosystems (Adriaens et al. 2003). Harmonia axyridis was recorded most commonly in gardens and parks, road verges, forests 


\begin{tabular}{|l|lll|}
\hline & Journal : Small 10526 & Dispatch : 26-10-2007 & Pages : 17 \\
& Article No. : 9132 & $\square$ LE & $\square$ TYPESET \\
MS Code : BICO 634 & $\checkmark \mathrm{CP}$ & $\checkmark$ DISK \\
\hline
\end{tabular}

P. M. J. Brown et al.

and woodland fringes, but it also occurred in other habitats such as heathlands, meadows and wetlands (Adriaens et al. submitted to BioControl SI). By 2006, H. axyridis was recorded in all regions of Belgium (Fig. 1). The Coccinula database (data from 1999 to 2007) shows that $H$. axyridis was the most abundant coccinellid in Flanders, in terms of the total number of individuals recorded (excluding overwintering groups, which would have made $H$. axyridis abundance even higher). Harmonia axyridis was recorded in $76 \%$ (426 of 560) of sampled $5 \mathrm{~km}^{2}$ in Flanders, making it the second highest occurring coccinellid after Coccinella septempunctata L. (Coleoptera: Coccinellidae). In Belgium as a whole, H. axyridis was recorded in 49\% (557 of 1139) of sampled $5 \mathrm{~km}^{2}$, making its occurrence fifth highest after C. septempunctata, Propylea quatuordecimpunctata (L.) (Coleoptera: Coccinellidae), Adalia bipunctata (L.) (Coleoptera: Coccinellidae) and Thed vigintiduopunctata L. (Coleoptera: Coccinellidae). A full account of the spread of H. axyridis in Belgium is provided by Adriaens et al. (submitted to BioControl SI).

\section{Czech Republic}

The flightless strain of $\mathrm{H}$. axyridis was introduced into hop gardens in northwestern Czech Republic in 2003, but the species did not apparently establish at that time. The easterly

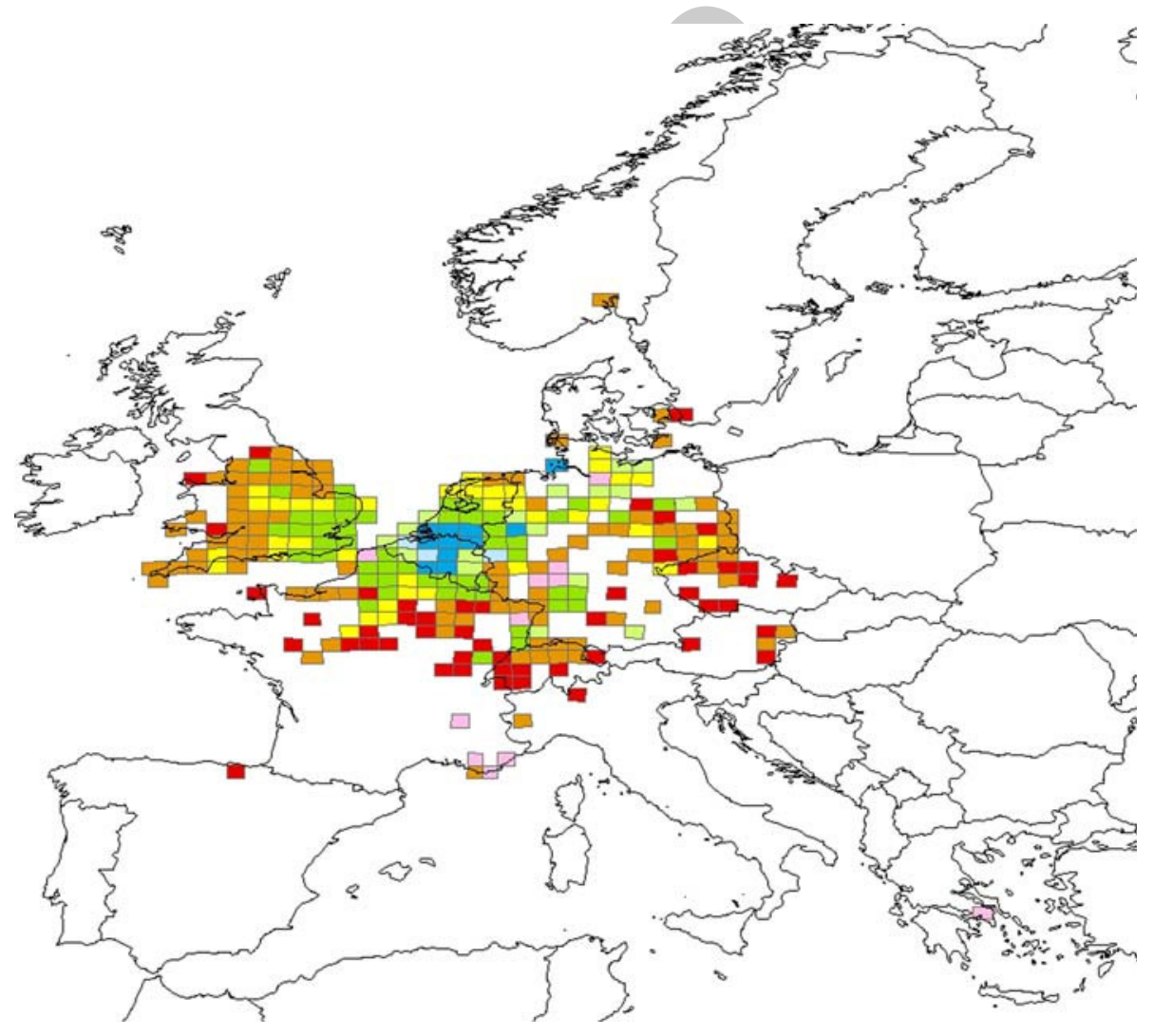

Fig. 1 Recorded occurrence of H. axyridis in $50 \mathrm{~km}^{2}$ in Europe. (Year of first known record: red = 2007; orange $=2006$; yellow $=2005$; dark green $=2004$; pale green $=2003$; dark blue $=2002$; pale blue $=$ 2001 ; pink $=$ pre 2001) 


\begin{tabular}{|l|lll|}
\hline & Journal : Small 10526 & Dispatch : 26-10-2007 & Pages : 17 \\
Article No. : 9132 & $\square$ LE & $\square$ TYPESET \\
MS Code : BICO 634 & $\checkmark$ CP & $\checkmark$ DISK \\
\hline
\end{tabular}

Harmonia axyridis in Europe

100 spread of $H$. axyridis from Germany is assumed to be the main cause of the species arriving 101 in the Czech Republic, where it was first recorded in the wild in 2006 in Prague and nearby 102 rural areas (O. Nedved and I. Kovár, unpublished data). In 2007, intentional monitoring was started (advertised at http://zoo.bf.jcu.cz/kz/harmonia.htm), resulting in records from all parts of Bohemia and northern Moravia, the eastern-most recorded locality of H. axyridis in Europe (Fig. 1). Records of ovipositing females and mature larvae confirmed that the species had established. Most $H$. axyridis were found on aphid infested woody plants: cherry Prunus avium L. (Rosaceae), mock-orange Philadelphus coronarius L. (Hydrangeaceae), steeple-bush Spiraea douglasii Hook (Rosaceae), willow Salix alba L. (Salicaceae), crab apple Malus sylvestris (L.) Mill. (Rosaceae) and pear Pyrus communis L. (Rosaceae). Based on the findings of mature larvae and ovipositing females, five 111 prey species; Aphis philadelphi Börner (Hemiptera: Aphididae), Aphis spiraecola Patch 112 (Hemiptera: Aphididae), Dysaphis plantaginea (Passerini) (Hemiptera: Aphididae), 113 Tuberolachnus salignus (Gmelin) (Hemiptera: Aphididae) and Cacopsylla pyri (L.) 114 (Hempitera: Psyllidae); may be considered as suitable (essential sensu Hodek 1973) prey 115 for $H$. axyridis.

\section{France}

117 Harmonia axyridis was first introduced to France from China by the Institut National de la 118 Recherche Agronomique (INRA) (http://www.inra.fr) in 1982 (Iperti and Bertand 2001), 119 but was in quarantine until 1990 (Kabiri 2006). Between 1990 and 1997 field experiments 120 and releases were carried out, especially in southeastern France, but also in the north of the country and near Paris (Coutanceau 2006). Mass production of $H$. axyridis in France began in 1992 and the first open-air commercial field releases were in 1995 (Kabiri 2006). The species is regarded by Coutanceau (2006) to have become acclimatized in France by 1991. The earliest known record in the wild is of two individuals, both of the colour form f. spectabilis (Fig. 2), found at Saint-Aubin (Lot-et-Garonne) in southwestern France in

126 November 1991 (Coutanceau 2006). Harmonia axyridis was recorded at five overwintering 127 sites in southern France between 1992 and 1993 (Coutanceau 2006) and at Pas-de-Calais in 128 northern France, where it was released in hops in 1994 (Trouvé 1995). There are very few 129 known records of $H$. axyridis in France from 1995 to 2003, but from 2004 it was widely 130 established (Coutanceau 2006) and by 2007 was found across much of northern France 131 (Fig. 1). It is unknown whether the sparseness of records prior to 2004 is a result of lack of 132 recording effort, or genuine scarcity of $H$. axyridis in France at that time. Certainly, since 1332004 the recording effort in France has increased, principally due to the launch of a 134 dedicated survey (Observatoire H. axyridis-http://perso.orange.fr/vinc.ternois/cote_ 135 nature/Harmonia_axyridis). This is now a well organised survey with in excess of 120 136 contributors in 15 French regions, each having a regional co-ordinator.

\section{Germany}

138 Although officially never sold in Germany, H. axyridis was released in Frankfurt between 1391997 and 1998 to control aphids on roses (H. Bathon, unpublished data). It was 140 first recorded in the wild in 1999 in Hamburg (Tolasch 2002) and Frankfurt-Niederrad 141 (H. Bathon, unpublished data). By 2000, H. axyridis was common in the Rhein-Main region 142 and there was major expansion of the species in Germany by 2002 (Klausnitzer 2002). 


\begin{tabular}{|l|lll|}
\hline & Journal : Small 10526 & Dispatch : 26-10-2007 & Pages : 17 \\
Article No. : 9132 & $\square$ LE & $\square$ TYPESET \\
MS Code : BICO 634 & $\checkmark \mathrm{CP}$ & $\checkmark$ DISK \\
\hline
\end{tabular}

P. M. J. Brown et al.

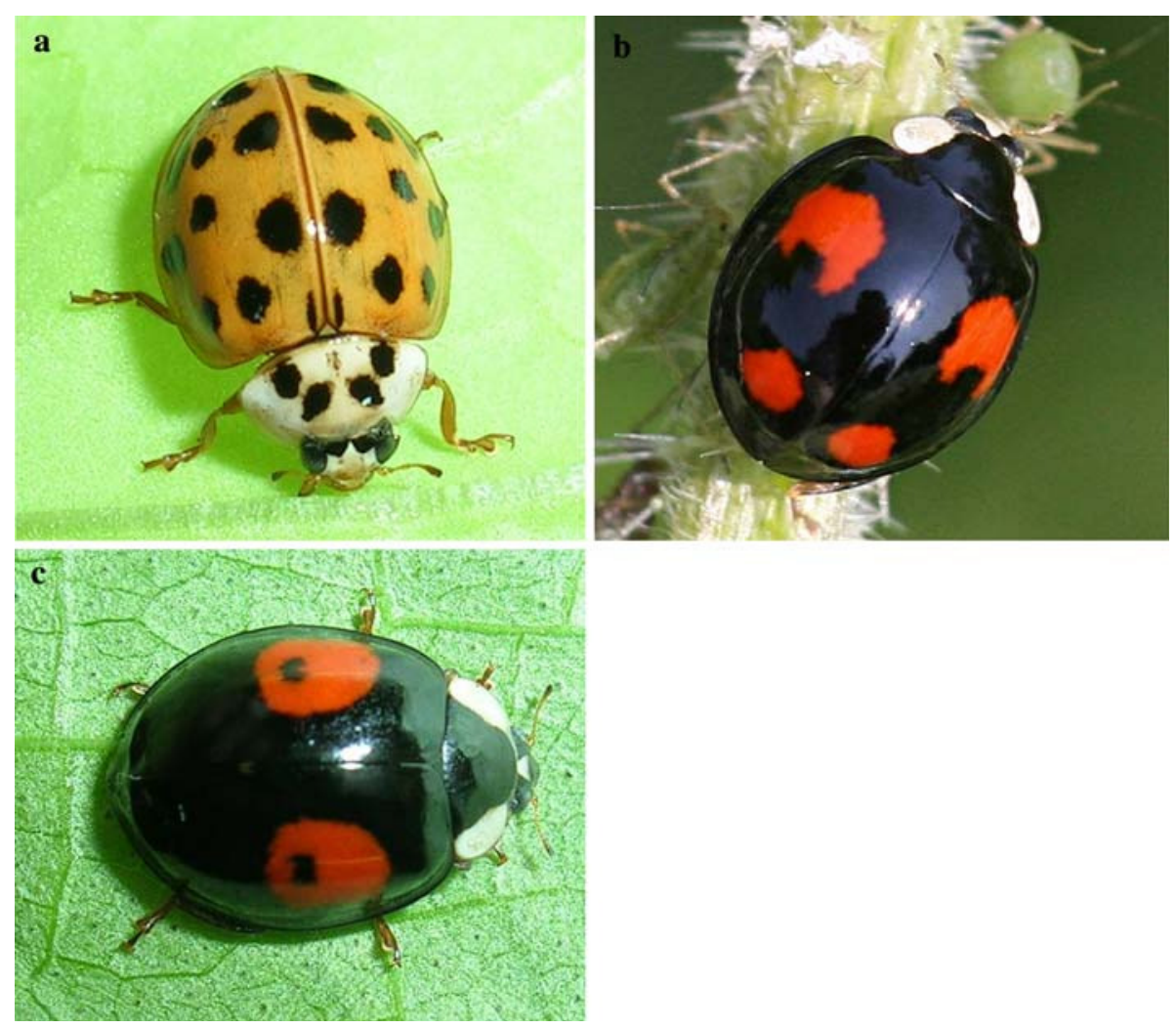

Fig. $2 H$. axyridis f. succinea, f. spectabilis and f. conspicua. (a) (C) Gavin Hatt, John Innes Centre Entomology, (b) (c) Ken Dolbear, (c) (c) Gavin Hatt, John Innes Centre Entomology

143 By 2006, H. axyridis occurred in all regions of western Germany and was common in many 144 cities (F. Köhler, personal communication). The species is well recorded in central eastern 145 Germany from 2006, but there are few records from the northeast or southeast of the country 146 (Fig. 1). This may be due to lower recording effort rather than genuine absence of the 147 species.

\section{Greece}

149 French stock of $H$. axyridis was introduced into four citrus-growing areas of Greece in 1501994 (Katsoyannos et al. 1997). From 1995 to 1999 over 100,000 adult H. axyridis were 151 released in central and southern Greece and on several islands, to control aphids on various 152 crops (including citrus, vegetables, beans and maize) (Kontodimas et al. in press). Further 153 releases took place from 1997 to 2002, mainly in urban areas (Attica and Peloponessos 154 regions, Corfu, Rhodes and Crete) (Kontodimas et al. in press). Despite these major 155 releases and four overlapping generations of $H$. axyridis being reported in Greece 156 (Katsoyannos et al. 1997), there is little evidence of establishment of the species, although 157 small numbers $(<50)$ of overwintered adults were found in Attica in spring 1998 and 1999 158 (Kontodimas et al. in press) (Fig. 1). 


\begin{tabular}{|l|lll|}
\hline & Journal : Small 10526 & Dispatch : 26-10-2007 & Pages : 17 \\
& Article No. : 9132 & $\square$ LE & $\square$ TYPESET \\
& MS Code : BICO 634 & $\vee$ CP & $\nabla$ DISK \\
\hline
\end{tabular}

Harmonia axyridis in Europe

Italy

160 Harmonia axyridis was used as a biological control agent in greenhouses in northern Italy in the 1990s. The first known sighting of $H$. axyridis naturalised in Italy, was in Turin in October 2006, when approximately 30 specimens, including pupae, were found on trees of an Acer sp. (Aceraceae) (I. Zakharov, unpublished data) (Fig. 1). It is unknown whether these ladybirds originated from escaped specimens within Italy, or are immigrants from southern France or Switzerland. In July 2007, a few adult $H$. axyridis were found at two sites in the Piedmont region (M. Kenis, unpublished data), presenting further evidence of establishment in northeastern Italy.

Netherlands

169 Harmonia axyridis was marketed as a biological control insect in the Netherlands from 170 approximately 1996 (Cuppen et al. 2004) until 2003. The first record of $H$. axyridis 171 naturalised in the Netherlands was in October 2002, when a pupa was found on an ivy 172 Hedera helix L. (Araliaceae) leaf in Nijmegen. A larva of $H$. axyridis was confirmed in 173 Rotterdam the following month. Initial distribution was reported primarily in the southern half of the country. Numbers of $H$. axyridis rose dramatically from 2004 (Loomans 2004) and survey effort was increased from that year, with records requested via three Dutch websites (http://www.stippen.nl, http://www.knnv.nl and http://www.nev.nl). The species appears to have spread from south to north, and by 2006 all mainland $50 \mathrm{~km}^{2}$ in the Netherlands had records of $H$. axyridis (Fig. 1). Over 2000 records of the species were received between 2002 and 2007.

Between 1984 and 1985, H. axyridis was used to control aphids on citrus crops in the Algarve province of Portugal, and on the Portuguese administered islands of the Azores (Katsoyannos et al. 1997; Soares et al. submitted to BioControl SI). There is no evidence of subsequent establishment. However, recent work by Soares and Serpa (2007) concluded that if re-introduced to the Azores, $H$. axyridis would present a risk to the native species

188 In $1995 H$. axyridis was introduced to control aphids on greenhouses in Almeria, 189 southeastern Spain (SIFA 2004). It established in greenhouses (Jacas et al. 2006), but 190 there is no evidence of subsequent establishment in the wild. In 2003 and 2004 two specimens of $H$. axyridis were found in a garden on Tenerife, Canary Islands and it was

192 found again on the island in 2006 (S. Eizaguirre, personal communication). There are no official reports of introductions of $H$. axyridis for agricultural purposes from the Canary government, and the species is not believed to be present in large numbers (Machado 2005). In 2007, two adult $H$. axyridis were collected from flowers of a Tilia platyphyllos

196 Scop. (Tiliaceae) tree in a park in Loiu, Bilbao, Basque country of northern Spain 197 (A. Goldarazena, unpublished data) (Fig. 1). This is the first record of naturalised 


\begin{tabular}{|l|lll|}
\hline & Journal : Small 10526 & Dispatch : 26-10-2007 & Pages : 17 \\
Article No. : 9132 & $\square$ LE & $\square$ TYPESET \\
MS Code : BICO 634 & $\checkmark \mathrm{CP}$ & $\checkmark$ DISK \\
\hline
\end{tabular}

P. M. J. Brown et al.

198 H. axyridis in the Iberian peninsula. There is no evidence that $H$. axyridis was released 199 for biological control purposes in the Basque country (R. Amenabar, personal commu200 nication). The specimens are likely to have either originated from France, or from 201 imported goods entering the nearby Bilbao airport.

202 Switzerland

203 Harmonia axyridis was available commercially in Switzerland for a short period in the late 204 1990s, and was used in a small field trial on roses in Grossdietwil in 1996 (Andermatt 205 1996). However, H. axyridis did not apparently establish as a result, and applications for 206 the commercial release of the species were refused by the Swiss Pesticide Regulatory 207 Authority in 1997 (van Lenteren et al. submitted to BioControl SI). No adults were found 208 in the wild in Switzerland until 2004, when a single specimen was found at an exhibition of 209 Asian plants in Basle (Klausnitzer 2004). Harmonia axyridis was not found during surveys 210 in 2005, but in 2006 it was recorded in ten cantons in northern Switzerland (Eschen et al. 211 2007), and larvae of the species were found for the first time in Switzerland. The higher 212 abundance of the beetle near the northern border suggests that it invaded the country from 213 southern Germany and/or eastern France. In a large survey for ladybirds in northwestern

214 Switzerland, $H$. axyridis was found to be the seventh most abundant species on trees and 215 shrubs, and the first cases of aggregations on buildings were notified in autumn 2006 in 216 Basle, where the species was the most abundant coccinellid at some sites (Eschen et al. 217 2007). The monitoring continued in 2007 and a dedicated website was launched 218 (http://www.cabi-bioscience.ch/harmonia). By late 2007, the ladybird was found in most 219 Swiss cantons (Fig. 1).

\section{Countries in which $\boldsymbol{H}$. axyridis has been found in the wild without evidence 221 of deliberate introduction}

222 Austria

223 In Europe and North America, the attraction of $H$. axyridis to buildings for use as over224 wintering sites (Koch 2003) has increased the number of sightings of the species. The first published record in Austria (October 2006; Wiener Neustadt, eastern Austria) was one such sighting, where several adult specimens of $H$. axyridis were found on a house wall searching for an overwintering site (Rabitsch and Schuh 2006). An earlier record subsequently came to light, in which $H$. axyridis larvae were found on plants on a balcony in nearby Vienna in July 2006, and there are several later records of adults in Vienna in 2006 and 2007 (W. Rabitsch, unpublished data). Harmonia axyridis is clearly established in Austria, and independent observations in the west (Götzis, October 2006; Rankweil, April 2007; Vorarlberg, August 2007), centre (Salzburg, May 2007), and south (Herberstein, July 2007) of the country (W. Rabitsch, unpublished data), support the hypothesis of spread from Switzerland and/or Germany (Fig. 1). There is no known evidence that $H$. axyridis was used for biological control purposes in Austria, making it less likely that the spread resulted from (illegally) imported specimens escaped from greenhouses or gardens. The scattered documentation of $H$. axyridis in Austria reflects the largely unnoticed expansion in the country. No large aggregations have yet been reported, with the maximum number from a single site (Vienna) being approximately 20 adult $H$. axyridis. 


\begin{tabular}{|l|lll|}
\hline & Journal : Small 10526 & Dispatch : 26-10-2007 & Pages : 17 \\
& Article No. : 9132 & $\square$ LE & $\square$ TYPESET \\
& MS Code : BICO 634 & $\vee$ CP & $\checkmark$ DISK \\
\hline
\end{tabular}

Harmonia axyridis in Europe

Denmark

241 The first known record of $H$. axyridis in Denmark was in Copenhagen in July 2006

250 The first record of H. axyridis in Great Britain, in September 2004, initiated considerable media and public interest, and led to the launch of the web-based Harlequin Ladybird Survey (http://www.harlequin-survey.org) (Majerus et al. 2006; Roy et al. 2006). Thanks to thousands of contributors across Britain, the species has been recorded and mapped at high resolution (Roy et al. 2005; Brown et al. submitted to BioControl SI) and its rapid spread north and west from the southeast is clear (Fig. 1). By mid 2007, H. axyridis was recorded in $88 \%$ of English and $38 \%$ of Welsh vice counties. It was also found on the island of Jersey, Channel Islands. We predict that it will continue to spread north and reach Scotland by the end of 2008. Three colour forms have been recorded in Britain; f. succinea, f. spectabilis and f. conspicua (Fig. 2). A detailed account and analysis of the spread of H. axyridis in Great Britain is provided by Brown et al. (submitted to BioControl SI).

Liechtenstein

Harmonia axyridis was found for the first time in the tiny principality of Liechtenstein in August 2007 (A. Loomans, unpublished data). The whole principality is contained within a single $50 \mathrm{~km}^{2}$ in which there were earlier records for both Austria and Switzerland.

Luxembourg

Considering that the border areas of France, Belgium and Germany that surround Luxembourg were all known to have populations of $H$. axyridis (Fig. 1), it was inevitable that the species would arrive in this small country. It was present by September 2004, when first recorded on Acer pseudoplatanus L. (Aceraceae) in the south of Luxembourg (Schneider and Loomans 2006). Further sightings of $H$. axyridis were made in October, November and December 2004 in urban locations (Schneider and Loomans 2006) and large reproducing populations were recorded in August 2005 in the north (Clervaux) and south (Luxembourg City) of the country (M. Majerus, unpublished data).

Norway

Whilst there is no evidence that $H$. axyridis is established in Norway, it has been recorded in Oslo, having been found on horticultural plants imported from the Netherlands in April 2006 (Staverloekk et al. in press) (Fig. 1). 


\section{Sweden}

279 Harmonia axyridis was first recorded in Sweden in Malmö in April 2007 (T. Hägg, 280 unpublished data), when a single adult was found in a house (Fig. 1). Subsequently, a dead 281 adult was found at the same location, and it is thought that the species had been over282 wintering in the house, suggesting that it arrived in late 2006, possibly from Germany or 283 Denmark. There are no other known records of $H$. axyridis in Sweden.

\section{Establishment and spread}

285 Harmonia axyridis has spread in Europe at a very fast rate (Table 1; Fig. 3). It is not 286 possible to fully explain the mechanisms of spread leading to the current distribution, 287 because of the spatial and temporal aspects of the deliberate releases of $H$. axyridis. This 288 involved multiple introduction sites in at least twelve European countries over a period of 289 approximately forty years (Table 1).

290 Time lags may occur throughout the invasion process, including the arrival, estab291 lishment and impacts of the invading species (Crooks 2005). Our data indicates a variable 292 time lag between initial establishment and major expansion, at least in the countries where 293 H. axyridis was deliberately introduced. In France this time lag was approximately

Table 1 Summary of H. axyridis occurrence in Europe

\begin{tabular}{|c|c|c|c|c|}
\hline Country & $\begin{array}{l}\text { Year of first } \\
\text { record in the } \\
\text { wild }\end{array}$ & $\begin{array}{l}\text { Deliberately introduced? } \\
\text { (Earliest year of } \\
\text { introduction) }\end{array}$ & $\begin{array}{l}\text { Evidence of } \\
\text { establishment? }\end{array}$ & $\begin{array}{l}\text { No. } 50 \mathrm{~km}^{2} \text { with } \\
\text { H. axyridis } \\
\text { by August } 2007\end{array}$ \\
\hline Ukraine & Unknown & Yes (1964) & Unknown & Unknown \\
\hline Belarus & Unknown & Yes (1968) & Unknown & Unknown \\
\hline Portugal & N/A & Yes (1984) & No & 0 \\
\hline France & 1991 & Yes (1982) & Yes & 63 \\
\hline Greece & 1998 & Yes (1994) & Limited & 1 \\
\hline Germany & 1999 & Yes (1997) & Yes & 75 \\
\hline Belgium & 2001 & Yes (1997) & Yes & 21 \\
\hline Netherlands & 2002 & Yes (1996) & Yes & 26 \\
\hline $\begin{array}{l}\text { Spain, including } \\
\text { Canary Islands }\end{array}$ & 2003 & Yes (1995) & No & 2 \\
\hline Switzerland & 2004 & Yes (1996) & Yes & 15 \\
\hline Luxembourg & 2004 & No & Yes & 2 \\
\hline $\begin{array}{l}\text { England and } \\
\text { Channel Island }\end{array}$ & 2004 & No & Yes & 60 \\
\hline Italy & 2006 & Yes (1990s) & Yes & 1 \\
\hline Czech Repub & 2006 & Yes (2003) & Yes & 11 \\
\hline Austria & 2006 & No & Yes & 7 \\
\hline Denmark & 2006 & No & Yes & 2 \\
\hline Wales & 2006 & No & Yes & 5 \\
\hline Norway & 2006 & No & No & 1 \\
\hline Liechtenstein & 2007 & No & Yes & 1 \\
\hline Sweden & 2007 & No & No & 1 \\
\hline
\end{tabular}




\begin{tabular}{|l|lll|}
\hline & Journal : Small 10526 & Dispatch : 26-10-2007 & Pages : 17 \\
& Article No. : 9132 & $\square$ LE & $\square$ TYPESET \\
MS Code : BICO 634 & $\checkmark \mathrm{CP}$ & $\checkmark$ DISK \\
\hline
\end{tabular}

Harmonia axyridis in Europe

Fig. 3 Cumulative occurrence of $H$. axyridis in $50 \mathrm{~km}^{2}$ in Europe

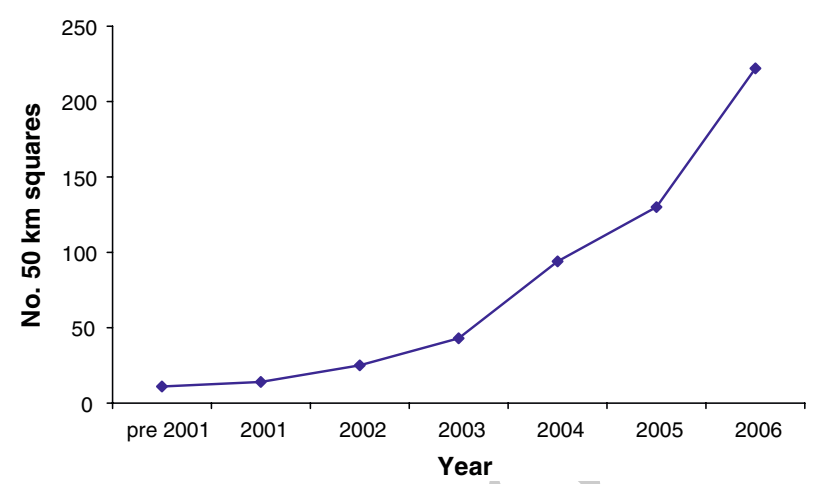

294

295

296

297

298

299

300

301

302

303

304

305

306

307

308

309

310

311

312

313

314

315

316

317

318

319

320

321

322

323

324

325

326

327

328

13 years (i.e. 1991-2004), in the Netherlands approximately 6 years (i.e. 1996-2002), and in Belgium approximately 4 years (i.e. 1997-2001). In countries where the species has not known to have been introduced, there seems to be very little time lag between the first record of establishment and major expansion (e.g. less than one year in England). The period between establishment and rapid spread in the USA is difficult to assess because of multiple intentional releases over many years (Gordon 1985), uncertainty over the date of establishment, and ambiguity over whether an intentional release or an accidental introduction was the source of establishment (Day et al. 1994; Koch 2003).

The reasons for the time lag between establishment of $H$. axyridis and major expansion in Europe are as yet unknown. However, it is possible that it is related to the genetic makeup of releases, and to differences between environmental conditions in the locations where released stocks originated and where they were released. The genetic make-up of released stocks would be a function of selection acting to locally adapt populations in their native range before collection, and random genetic drift and selection acting on laboratory cultures before release. It is likely that some cultures passed through genetic bottlenecks while in culture. Moreover, there are reports of rapid changes in some obvious genetically controlled traits in laboratory cultures. For example, the phenotypic frequencies of melanic forms (f. conspicua and f. spectabilis) of a laboratory population increased from 0.5 to $>0.99$ in 50 generations (Berkvens et al. submitted to BioControl SI). As many laboratory cultures are maintained on diets that $H$. axyridis would not encounter in the wild (i.e. Ephestia eggs), it is inevitable that released beetles will have been exposed to abnormal selection pressures in captivity. In consequence, it is highly unlikely that released individuals will be precisely adapted to the conditions that they face in their introduced range. In many cases, releases therefore do not lead to establishment, as recorded for $H$. axyridis in the USA (Gordon 1985) and Greece (Kontodimas et al. in press). However, if we assume that at least some individuals do survive and reproduce, the expectation would be that these would take time to start increasing in number significantly, for two reasons. First, because of their as yet imperfect adaptation to local conditions, and second because at low population size they are likely to suffer the effects of inbreeding depression, which is considerable in many aphidophagous coccinellids (Hodek 1973; Majerus 1994, 2003). There will thus be a period after establishment during which the average fitness of members of the population increase as the population is purged of deleterious recessives (Haldane 1927), and slowly becomes better locally adapted to the new conditions, through selection acting on the genotypic variation generated by recombination and mutation (Fisher 1930). It is only once the population has become locally adapted that it will start to 


\begin{tabular}{|l|lll|}
\hline & Journal : Small 10526 & Dispatch : 26-10-2007 & Pages : 17 \\
Article No. : 9132 & $\square$ LE & $\square$ TYPESET \\
MS Code : BICO 634 & $\checkmark \mathrm{CP}$ & $\checkmark$ DISK \\
\hline
\end{tabular}

P. M. J. Brown et al.

increase in number. However, the rate of increase may then be rapid for two reasons. First, the population may have been purged of deleterious recessive alleles, as mentioned above. Second, while in culture the released beetles may have been inadvertently selected for rapid reproduction, high fecundity and broad dietary range; biological control companies reared large numbers as efficiently as possible for commercial reasons. Once numbers in a released population increased sufficiently to approach carrying capacity, increased rate of dispersal would be inevitable as the beetles sought new resources. The rate of this process may vary greatly depending on factors such as the size of the original samples collected from the native range, the number of different populations that such samples were collected from, the length of time and number of generations that cultures were kept in captivity for before release, the number of individuals that founded each culture generation, and the number of beetles finally released. If releases involved stocks with quite different origins, then the speed of local adaptation would be faster than if all released beetles were from a single stock. This is because matings between individuals from different locally adapted populations would produce a greater range of genetic variants among their offspring for selection to act upon.

The initial need for adaptation before increase in number and spread may explain the lack of a time lag between establishment and major expansion in countries where $H$. axyridis was not deliberately introduced; individuals of $H$. axyridis arriving in these countries from parts of the introduced range had already been through the adaptation phase. So after a period of adaptation of one or several populations in France, Netherlands, Belgium and/or Germany, a rapid spread of $H$. axyridis occurred throughout Europe.

\section{Genetic variation and the origins of $\boldsymbol{H}$. axyridis in Europe}

Three main colour forms of adult $H$. axyridis have been found in Europe: f. succinea, f. spectabilis and f. conspicua (Fig. 2). The typical form axyridis, which predominates in central Asia (Dobzhansky 1933; I. Zakharov and M. Majerus, personal observation), has not yet been recorded in Europe. The succinea complex has been divided into many subforms (e.g. siccoma-0 spots; frigida-6 spots; novemdecimsignata-19 spots) (Dobzhansky 1933), but is regarded as a single form here. Thus f. succinea has elytra with a ground colour of yellow, orange, or red, and 0-21 black spots, which may or may not be fused. Forma spectabilis has black elytra with four yellow, orange, or red spots or other shaped markings, which sometimes contain a central black spot. Forma conspicua is as f. spectabilis, but with only the anterior pair of spots.

There is strong evidence of a link between climate and colour form in coccinellids (e.g. Majerus 1994, 1998). Whilst the basis of difference in distinct colour form (e.g. f. succinea cf. f. spectabilis) is genetic, difference in colouration within a form is at least partly environmental. For example, in many species of coccinellid, inverse correlations between temperature and extent of melanic patterning have been reported (e.g. Dobzhansky 1933; Abbas et al. 1988; Majerus 1998). In the case of $H$. axyridis, the amount of melanism in f. succinea was found to increase at high elevations (Nalepa et al. 1996).

European populations of $H$. axyridis generally include a mix of the three colour forms, but with f. succinea predominating (Fig. 4). Interestingly, in England the percentage of melanic specimens declined markedly from the year of arrival of $H$. axyridis, 2004 (45\%, $n=344)$ (Majerus and Roy 2005) to the second year, $2005(20 \%, n=6180)$ (M. Majerus, unpublished data). The broad consistency in the colour form frequency data from Europe (Fig. 4) provides some evidence of the genetic similarity of populations in different 


\begin{tabular}{|l|lll|}
\hline & Journal : Small 10526 & Dispatch : 26-10-2007 & Pages : 17 \\
& Article No. : 9132 & $\square$ LE & $\square$ TYPESET \\
MS Code : BICO 634 & $\checkmark \mathrm{CP}$ & $\checkmark$ DISK \\
\hline
\end{tabular}

Harmonia axyridis in Europe

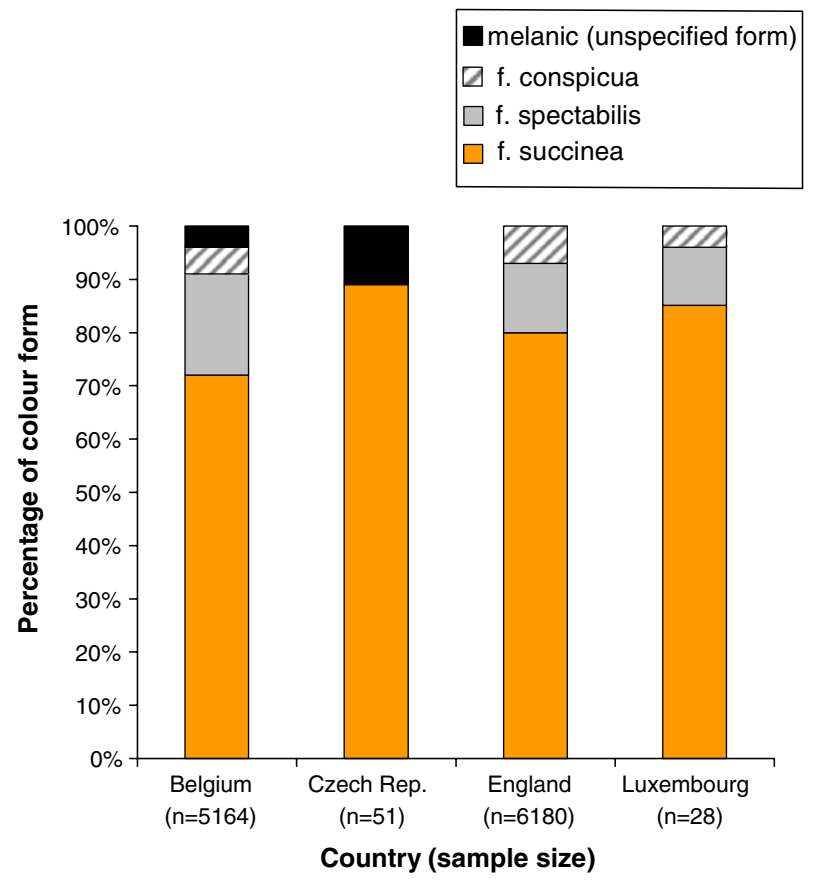

Fig. 4 Percentages of $H$. axyridis colour forms in various countries (Belgium data from 2004-2006 (Adriaens et al. submitted to Biocontrol SI), Czech Republic data from 2006-2007 (O. Nedved, unpublished data), England data from 2005 (M. Majerus, unpublished data), Luxembourg data from 2004 (Schneider and Loomans 2006))

European countries. Further, we suggest that this possible genetic similarity is the result of spread of the species from very limited points of origin in Europe. Genetic analyses of H. axyridis samples from different countries are needed in order to confirm this.

\section{Traits that give $\boldsymbol{H}$. axyridis a competitive advantage over native coccinellids}

379 In Europe, H. axyridis has been shown to be multi-voltine, with evidence of four gener380 ations per year in Greece (Katsoyannos et al. 1997) and two generations per year in Great 381 Britain (Brown et al. submitted to BioControl SI). Production of multiple generations would help to explain the rapid spread of $H$. axyridis in Europe. In northern Europe, many native coccinellids are uni-voltine (Majerus 1994; Klausnitzer and Klausnitzer 1997), thus $H$. axyridis may have a significant advantage over them in terms of potential population growth. Dispersal of $H$. axyridis in northern Europe appears to occur primarily in autumn, when the species moves to aggregate at overwintering sites. This pattern is similar to that observed in North America (Koch 2003). Large overwintering aggregations have been observed in several European countries including Belgium, the Netherlands, France, Germany and England.

Recent European research has provided further evidence of the adaptability and resilience of $H$. axyridis. In laboratory experiments, 35-48\% of $H$. axyridis larvae fed a pollenonly diet successfully reached adulthood, and although fitness was reduced, approximately 


\begin{tabular}{|l|lll|}
\hline & Journal : Small 10526 & Dispatch : 26-10-2007 & Pages : 17 \\
& Article No. : 9132 & $\square$ LE & $\square$ TYPESET \\
MS Code : BICO 634 & $\checkmark \mathrm{CP}$ & $\checkmark$ DISK \\
\hline
\end{tabular}

P. M. J. Brown et al.

\section{Conclusion}

\section{References} Europe.

$40 \%$ of these adult females produced viable eggs (Berkvens et al. submitted to BioControl SI). Roy et al. (submitted to BioControl SI) found that only the highest dose $\left(10^{9}\right.$ spores $\mathrm{ml}^{-1}$ ) of the fungal pathogen Beauveria bassiana (Balsamo) Vuillemin (Ascomycota: Hypocreales) killed $H$. axyridis, whereas two other species included in the study (A. bipunctata and C. septempunctata) experienced high mortality (70\% and $80 \%$ respectively) at a medium dose $\left(10^{7}\right.$ spores $\left.\mathrm{ml}^{-1}\right)$ of the pathogen. Koyama and Majerus (submitted to BioControl SI) found that $H$. axyridis had lower susceptibility than C. septempunctata to the parasitoid wasp Dinocampus coccinellae (Schrank) (Hymenoptera: Braconidae). Recent work on intraguild predation (Pell et al. submitted to BioControl SI; Roy et al. in press; Ware and Majerus submitted to BioControl SI; Ware et al. in press) indicates that $H$. axyridis will have a serious negative impact on native coccinellids in

We predict that $H$. axyridis will continue to spread in Europe, particularly northwards and eastwards. Northwards there are already initial records from Norway and Sweden, and whilst there is little evidence of establishment to date, this is likely in the near future. Spread into the Baltic states and Finland is also likely. Given that $H$. axyridis survives as a native species in parts of Siberia, the climate in these countries should not be a barrier to establishment. Eastwards it is entirely possible, (indeed likely), that the species is already present, but undetected, in countries such as Poland, Slovakia, Hungary and Slovenia. Ireland is the only remaining country left to be invaded from the westward spread, and we predict that $H$. axyridis will reach there, from Great Britain, in the relatively near future, and once established will spread across the whole country. The spread southwards is less certain, although as the species is adapted to Mediterranean and sub-tropical climates in parts of its native range (southern Japan and China), it may gradually adapt to the warmer climes of southern Europe, the Iberian peninsular and north Africa, and eventually establish and spread there. Indeed there are already initial reports of establishment in Egypt (S. Elnagdy, personal communication). Over a very short time period $H$. axyridis is likely to become one of the most widely distributed coccinellids in Europe. It remains to be seen what effect this will have on native/coccinellids, but mounting evidence suggests a seriously detrimental impact.

Acknowledgements We extend our thanks to all of the following: the thousands of volunteer recorders and naturalists across Europe who have provided records; others who have provided records and support, including; Manfred Bernhard, Gernot Hoch, Erwin Holzer, Andreas Kapp (Austria); Burkhard Hinnersmann, Frank Köhler, Manfred Uhlig (Germany); Theodoor Heijermans, Kees van der Krieke, Paul van Wielink, (Netherlands); Arnstein Staverloekk (Norway); David Calvo (Spain); Natural Environment Research Council, Paul Mabbott, Laura-Jane Michie, Remy Ware, Ian Wright (UK); Gavin Hatt and Ken Dolbear for permission to use their images. We are grateful for support from the DAISIE (Delivering Alien Invasive Species Inventories for Europe) project funded by the European Community's Sixth Framework Programme (contract no. GOCE-2004-511202).

Abbas I, Nakamura K, Katakura H, Sasaji H (1988) Geographical variation of elytral spot patterns in the phytophagous ladybird, Epilachna vigintioctopunctata (Coleoptera: Coccinellidae) in the province of Sumatra Barat, Indonesia. Res Population Ecol 30:43-56 


\begin{tabular}{|l|llll|}
\hline & Journal : Small 10526 & Dispatch : & $\mathbf{2 6 - 1 0 - 2 0 0 7}$ & Pages : 17 \\
& Article No. : $\mathbf{9 1 3 2}$ & $\square$ LE & $\square$ TYPESET \\
\hline
\end{tabular}

Harmonia axyridis in Europe

439

440

441

442

443

444

445

446

447

448

449

450

451

452

453

454

455

456

457

458

459

460

461

462

463

464

465

466

467

468

469

470

471

472

473

474

475

476

477

478

479

480

481

482

483

484

485

486

487

488

489

490

491

492

493

494

495

496

497

Adriaens T, Branquart E, Maes D (2003) The multicoloured Asian ladybird Harmonia axyridis Pallas (Coleoptera: Coccinellidae), a threat for native aphid predators in Belgium? Belgian J Zool 133:195-196

Adriaens T, Maes D, San Martin G, Branquart E Invasion history, habitat preferences and phenology of the invasive coccinellid Harmonia axyridis in Belgium. BioControl (submitted to BioControl SI)

Andermatt M (1996) Marienkäferlarven als blattlaus-bekämpfungsmittel? Andermatt Biocontrol 3:10-11

Berkvens N, Bonte J, Berkvens D, Deforce K, Tirry L, De Clercq P Pollen as an alternative food for Harmonia axyridis. BioControl (submitted to BioControl SI)

Brown MW, Miller SS (1998) Coccinellidae (Coleoptera) in apple orchards of eastern West Virginia and the impact of invasion by Harmonia axyridis. Entomol News 109:143-151

Brown PMJ, Roy HE, Rothery P, Roy DB, Ware RL, Majerus MEN Harmonia axyridis in Great Britain: analysis of the spread and distribution of a non-native coccinellid. BioControl (submitted to BioControl SI)

Chapin JB, Brou VA (1991) Harmonia axyridis (Pallas), the third species of the genus to be found in the United States (Coleoptera, Coccinellidae). Proc Entomol Soc Wash 93:630-635

Colunga-Garcia M, Gage SH (1998) Arrival, establishment, and habitat use of the multicolored Asian lady beetle (Coleoptera: Coccinellidae) in a Michigan landscape. Environ Entomol 27:1574-1580

Coutanceau J-P (2006) Harmonia axyridis (Pallas, 1773): une coccinelle asiatique introduite, acclimatée et en extension en France. Bull Soc Entomol France 111:395-401

Crooks JA (2005) Lag times and exotic species: The ecology and management of biological invasions in slow-motion. Ecoscience 12:316-329

Cuppen J, Heijerman T, van Wielink P, Loomans A (2004) Het lieveheersbeestje Harmonia axyridis in Nederland: een aanwinst voor onze fauna of een ongewenste indringer (Coleoptera: Coccinellidae)? Nederlandse Faunistische Mededelingen 20:1-12

Day WH, Prokrym DR, Ellis DR, Chianese RJ (1994) The known distribution of the predator Propylea quattuordecimpunctata (Coleoptera, Coccinellidae) in the United States, and thoughts on the origin of this species and 5 other exotic lady beetles in eastern North America. Entomol News 105:244-256

de Almeida LM, da Silva VB (2002) First record of Harmonia axyridis (Pallas) (Coleoptera, Coccinellidae): a lady beetle native to the Palaearctic region. Rev Bras Zool 19:941-944

Dobzhansky T (1933) Geographical variation in ladybeetles. Am Nat 67:97-126

Eschen R, Babendreier D, Nauer S, Bigler F, Kenis M (2007) Surveys for ladybirds (Coleoptera: Coccinellidae) in Switzerland and confirmation of the presence of the invasive alien ladybird species Harmonia axyridis (Pallas). Mitteilungen der Schweizerischen Entomologischen Gesellschaft 80:7-14

Ferran A, El-Arnaouty S, Beyssat-Arnaouty V, Galal H (2000) Introduction and release of the coccinellid Harmonia axyridis Pallas for controlling Aphis craccivora Koch on faba beans in Egypt. Egypt J Biol Pest Control 10:129-136

Fisher RA (1930) The genetical theory of natural selection. Oxford University Press, Oxford

Gordon RD (1985) The Coleoptera (Coccinellidae) of America north of Mexico. J New York Entomol Soc 93:1-912

Haldane JBS (1927) A mathematical theory of natural and artificial selection, part V: selection and mutation. Proc Cambridge Philosophical Soc 28:838-844

Hodek I (1973) Life history and biological properties. In: Hodek I (ed) Biology of Coccinellidae. Dr W Junk, The Hague

Iperti G, Bertand E (2001) Hibernation of Harmonia axyridis (Coleoptera: Coccinellidae) in south-eastern France. Acta Soc Zool Bohem 65:207-210

Jacas J-A, Urbaneja A, Viñuela E (2006) History and future of introduction of exotic arthropod biological control agents in Spain: a dilemma? BioControl 51:1-30

Kabiri F (2006) Harmonia axyridis: a problem or a distraction? In: Regulation of biological control agents (REBECA), Wageningen, Netherlands, pp. 4-6 April 2006. http://www.rebeca-net.de/ downloads/Risk\%20assessment\%20macrobials\%20Kabiri.pdf

Katsoyannos P, Kontodimas DC, Stathas GJ, Tsartsalis CT (1997) Establishment of Harmonia axyridis on citrus and some data on its phenology in Greece. Phytoparasitica 25:183-191

Klausnitzer B (2002) Harmonia axyridis (Pallas, 1773) in Deutschland (Col.,Coccinellidae). Entomologische Nachrichten und Berichte 46:177-183

Klausnitzer B (2004) Harmonia axyridis (Pallas, 1773) in Basel-Stadt (Coleoptera, Coccinellidae). Entomologische Gesellschaft Basel 54:115-122

Klausnitzer B, Klausnitzer H (1997) Marienkäfer (Coccinellidae). 4. überarbeitete auflage. Die Neue Brehm-Bücherei, Magdeburg

Koch RL (2003) The multicolored Asian lady beetle, Harmonia axyridis: a review of its biology, uses in biological control, and non-target impacts. J Ins Sci 3:1-16 


\begin{tabular}{|l|llll|}
\hline & Journal : Small 10526 & Dispatch : & $\mathbf{2 6 - 1 0 - 2 0 0 7}$ & Pages : 17 \\
& Article No. : $\mathbf{9 1 3 2}$ & $\square$ LE & $\square$ TYPESET \\
\hline
\end{tabular}

P. M. J. Brown et al.

498

Kontodimas DC, Stathas GJ, Martinou AF Status of the aphidophagous predator Harmonia axyridis (Pallas) (Coleoptera: Coccinellidae) in Greece. Eur J Entomol (in press)

Koyama S, Majerus MEN Interactions between the parasitoid wasp Dinocampus coccinellae and two species of coccinellid from Japan and Britain. BioControl (submitted to BioControl SI)

Krafsur ES, Kring TJ, Miller JC, Nariboli P, Obrycki JJ, Ruberson JR, Schaefer PW (1997) Gene flow in the exotic colonizing ladybeetle Harmonia axyridis in North America. Biol Control 8:207-214

Kuznetsov VN (1997) Lady beetles of Russian far east. The Sandhill Crane Press, Gainesville, Florida

Loomans A (2004) Veelkleurig Aziatisch lieveheersbeestje Harmonia axyridis bezig aan een opmars in Nederland. Coccinula 10:62-63

Machado A (2005) El sarantontón asiático Harmonia axyridis (Pallas, 1773) presente en Canarias (Coleoptera: Coccinellidae). Vieraea 34:71-72

Majerus MEN (1994) Ladybirds. No. 81, new naturalist series. HarperCollins, London

Majerus MEN (1998) Melanism: evolution in action. Oxford University Press, Oxford

Majerus MEN (2003) Sex wars: genes, bacteria, and sex ratios. Princeton University Press, Princeton, New Jersey

Majerus MEN, Mabbott P, Rowland F, Roy HE (2006) The harlequin ladybird, Harmonia axyridis, arrives in Britain. Entomol Mon Magaz 142:87-92

Majerus MEN, Roy HE (2005) Scientific opportunities presented by the arrival of the harlequin ladybird, Harmonia axyridis, in Britain. Antenna 29:196-208

McClure MS (1987) Potential of the Asian predator, Harmonia axyridis Pallas (Coleoptera, Coccinellidae), to control Matsucoccus resinosae Bean and Godwin (Homoptera, Margarodidae) in the United States. Environ Entomol 16:224-230

Michaud JP (2002) Invasion of the Florida citrus ecosystem by Harmonia axyridis (Coleoptera: Coccinellidae) and asymmetric competition with a native species, Cycloneda sanguinea. Environ Entomol 31:827-835

Nalepa CA, Kidd KA, Ahlstrom KR (1996) Biology of Harmonia axyridis (Coleoptera: Coccinellidae) in winter aggregations. Ann Entomol Soc Am 89:681-685

Pell JK, Baverstock J, Roy HE, Majerus MEN, Ware RL Intraguild predation of native aphidophages by Harmonia axyridis; a review and future perspectives. BioControl (submitted to BioControl SI)

Rabitsch W, Schuh R (2006) First record of the multicoloured Asian ladybird Harmonia axyridis (Pallas, 1773) in Austria. Beiträge zur Entomofaunistik 7:161-164

Roy HE, Baverstock J, Ware RL, Clark SJ, Majerus MEN, Baverstock KE, Pell JK Intraguild predation of the aphid pathogenic fungus Pandora neoaphidis by the invasive coccinellid Harmonia axyridis. Ecol Entomol (in press)

Roy HE, Brown P, Majerus MEN (2006) Harmonia axyridis: a successful biocontrol agent or an invasive threat? In: Eilenberg J, Hokkanen H (eds) An ecological and societal approach to biological control. Kluwer Academic Publishers, Netherlands

Roy HE, Brown PMJ, Rothery P, Ware RL, Majerus MEN Interactions between the fungal pathogen Beauveria bassiana and three species of coccinellid: Harmonia axyridis, Coccinella septempunctata and Adalia bipunctata. BioControl (submitted to BioControl SI)

Roy HE, Rowland F, Brown PMJ, Majerus MEN (2005) Ecology of the harlequin ladybird: a new invasive species. Br Wildl 16:403-407

Schneider N, Loomans AJM (2006) Sur la présence au Luxembourg de la coccinelle arlequin Harmonia axyridis (Pallas, 1773) (Insecta, Coleoptera, Coccinellidae). Bulletin de la Société des Naturalistes Luxembourgeois 106:71-74

Sidlyarevich VI, Voronin KE (1973) Trials on using Leis axyridis under glass. Zashchita Rastenii 6:24

SIFA (Servicio de información fitosanitaria de Almería) (2004) Organismos de control biológico

Soares AO, Borges I, Borges PAV, Labries G, Lucas E Harmonia axyridis; What will stop the invader? BioControl (submitted to BioControl SI)

Soares AO, Serpa A (2007) Interference competition between ladybird beetle adults (Coleoptera: Coccinellidae): effects on growth and reproductive capacity. Popul Ecol 49:37-43

Staverloekk A, Saethre MG, Haagvar E A review of the biology of the invasive harlequin ladybird Harmonia axyridis (Pallas, 1773) (Coleoptera, Coccinellidae). Norwegian J Entomol (in press)

Tedders WL, Schaefer PW (1994) Release and establishment of Harmonia axyridis (Coleoptera, Coccinellidae) in the southeastern United States. Entomol News 105:228-243

Tolasch T (2002) Harmonia axyridis (Pallas, 1773) breitet sich in Hamburg aus - ausgangspunkt für en besiedlung mitteleuropas? Entomologische Nachrichten und Berichte 46:185-188

Trouvé C (1995) Essais de lutte biologique contre le puceron du houblon (Phorodon humuli) dans le nord de la France: résultats 1993 et 1994. In: 47th international symposium on crop protection, Ghent, 9 May 1995. Abstract book, p 109 


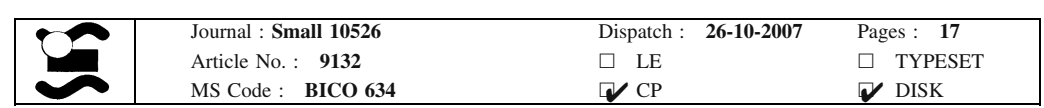

Harmonia axyridis in Europe

558 van Lenteren JC, Babendreier D, Bigler F, Burgio G, Hokkanen H, Kuske S, Loomans A, MenzlerHokkanen I, van Rijn P, Thomas M, Tommassini M, Zeng Q-Q (2003) Environmental risk assessment of exotic natural enemies used in inundative biological control. BioControl 48:3-38

van Lenteren JC, Loomans AJM, Babendreier D, Bigler F Harmonia axyridis: an environmental risk assessment for northwest Europe. BioControl (submitted to BioControl SI)

Ware RL, Evans N, O'Farrell K, Majerus MEN, Malpas L, Michie LJ Intraguild predation by the invasive ladybird Harmonia axyridis: 1: British and Japanese coccinellid eggs. Neobiota (in press)

Ware RL, Majerus MEN Intraguild predation of immature stages of British and Japanese coccinellids by the invasive ladybird Harmonia axyridis. BioControl (submitted to BioControl SI)

Ware RL, Majerus MEN, Roy HE, Symington F (2005) The harlequin ladybird arrives in Britain: a threat to our native species? Bull Amateur Entomol Soc 64:175-186 